\title{
Fungicide and Clay Treatments for Control of Powdery Mildew Influence Wine Grape Microflora
}

\author{
Peter Sholberg, Colleen Harlton, Julie Boulé, Paula Haag \\ Pacific Agri-Food Research Centre, Agriculture and Agri-Food Canada, 4200 \\ Highway 97, Summerland, B.C. VOH 1Z0, Canada
}

Additional index words. bacteria, 'Chancellor', fungi, 'Pinot noir', pseudomonads, 'Riesling', Uncinula necator, Vitis vinifera, yeast

\begin{abstract}
There is very little information on the interaction of wine grape microflora with fungicides used to control grape diseases. The objective of this study was to determine how fungicides used in a standard grape pest management program and an experimental clay being developed for control of powdery mildew affect grape microflora. Grape leaves and fruit were surveyed for bacteria, fungi and yeast six times over the growing season in 2000 after treatment with clay or fungicides. In 2001 only clay was studied for control of powdery mildew in 'Chancellor' grapes. The total number of propagules present on untreated leaf and fruit tissue were $76 \%$ bacteria, $14 \%$ yeast, and $9 \%$ fungi. Fungicides used for grape disease control significantly reduced epiphytic fungi $(P<0.0001)$, bacteria $(P=0.03)$, and yeast $(P=0.0001)$ on grape berries and epiphytic fungi $(P<0.0001)$, and yeast $(P=0.03)$ on leaves. The clay treatment had no detectable effect on grape microflora because no significant differences were recorded between clay or untreated grape berries or leaves on any of the sampling dates. Over the growing season the fungicide spray program reduced incidence and severity of powdery mildew better than clay. Clay controlled powdery mildew on 'Chancellor' fruit in 2000 and 2001.
\end{abstract}

The effect of fungicides on epiphytic grape microflora composed of bacteria, yeast, and fungi has not been seriously taken into consideration in grape pest management. The primary concern with pesticide use that has been addressed is the possibility of pesticide resistance. Strategies that have been developed to prevent fungicide resistance are the use of reduced number of applications, alternation, or mixtures of fungicides with different cross-resistance groups, and directing the fungicide against the most vulnerable stage of the pathogen in its life cycle (Jutsum et al., 1998). Little attention has been paid to the effect these materials might have on epiphytic bacteria, yeast, and fungi that could influence disease control and wine quality.

Bacteria colonize actively growing plant tissue first, while fungi, and yeast become prominent as tissue maturity approaches, and as the plant part becomes necrotic and dies (Leben, 1965). For this reason, epiphytic bacteria assume a central position, with importance in inciting frost damage to plants, altering plant development via exogenous phytohormone production and as agents of plant disease (Kinkel et al., 2000). Knowing whether epiphytic bacterial populations are immigration or growth limited has important implications on management of these populations (Lindow, 1996). On plants that harbour large numbers of bacteria (e.g., $10^{7} \mathrm{CFU} /$ leaf), growth appears to be the dominant process that determines bacterial population sizes (Upper and Hirano,

Received for publication 12 Aug. 2005. Accepted for publication 7 Nov. 2005.

${ }^{1}$ To whom reprint requests should be addressed; e-mail sholbergp@agr.gc.ca.
2002). Bacteria also occur within grape vines as was first documented by Bell et al. (1995) from vines found in Nova Scotia. Fungicides applied externally for control of plant pathogens could influence bacterial populations by killing sensitive bacteria.

Leaf surfaces are colonized by several genera of saprophytic yeasts generally categorized collectively as red yeasts (predominantly Sporobolomyces and Rhodotorula spp.), white yeasts (mainly Cryptococcus spp.), and the yeast-like fungus Aureobasidium pullulans (Andrews and Buck, 2002). This community of yeasts is thought to provide a natural buffer against plant pathogens (Fokkema et al., 1979) and individual yeast species have shown biological control potential against plant diseases (Andrews, 1992). A comparison of yeast counts shows that some plant surfaces have greater yeast populations than others (Davenport, 1976). Buds of 'Cascade' grapes had higher counts than leaves, and mature fruit had much higher counts than immature fruit. Yeast populations are influenced by climate and spray program. Rain reduces the yeast population (Longo et al., 1991) and grape temperature can determine which species are present. Hanseniaspora spp. is found in warm climates and Kloeckera is associated with cold temperatures (Villa and Longo, 1996). Commercial fungicides tend to inhibit fermentative yeast species favouring proliferation of oxidative or apiculate species (Villa and Longo, 1996). Sachromyces cerevisiae is quite sensitive to antifungal compounds whereas species belonging to Rhodotorula, Cryptotoccus, and Sporobolomyces show polyresistance to such agents (Villa and Longo, 1996). Therefore, yeast populations could be disrupted by fungicides which in turn could affect wine quality.

An important fungal plant pathogen of grapes is Erysiphe necator Schwein. var. necator (formerly Uncinula necator) which causes powdery mildew (Pearson, 1988) reducing yield and quality of juice and wine from infected grapes (Calonnec et al., 2004; Gadoury et al., 2001). Powdery mildew is controlled by several fungicides belonging to the demethylation-inhibiting, strobilurin, and quinoxyfen classes (Sholberg, 2004). It is also controlled by a number of organically produced materials in which sulphur is the most important member. Some other organics are mineral and vegetable oils (Northover and Schneider, 1996), potassium silicate (Reynolds et al., 1996), and clay (Ehret et al., 2001; Sholberg and Boulé, 2001). In addition to powdery mildew, bunch rot and phomopsis cane and leaf spot are important in grape pest management. Thus, in commercial vineyards fungicides are applied several times in a season according to a specific pest management program which attempts to control powdery mildew, bunch rot, and sometimes phomopsis cane and leaf spot while striving to prevent fungicide resistance. Because several different fungicides are repeatedly used throughout the season the natural microflora could be disrupted and this could have consequences for wine quality and disease control.

The objectives of this study were to 1) compare the microflora from one hybrid ('Chancellor) and two vinifera ('Pinot noir' and 'Riesling') grape cultivars; 2) monitor microflora on grape berries and leaves after each treatment (fungicide, clay, untreated) application to determine the effect on grape microflora; and 3) compare the conventional fungicide treatment with an organic clay treatment for control of powdery mildew.

\section{Materials and Methods}

Plot details. The trials were conducted at the Pacific Agri-Food Research Centre, Summerland, British Columbia, Canada (PARC) (lat. $49^{\circ} 34^{\prime} \mathrm{N}, 119^{\circ} 39 \mathrm{~W}$; elevation $454 \mathrm{~m}$ ) on 'Chancellor', 'Pinot noir', and 'Riesling' ownrooted wine grape cultivars. The vines were 16 -years old in 2000 with 'Chancellor' spaced at $2.5 \times 3.6 \mathrm{~m}$ in linear groups of adjacent vines consisting of three vines, 'Pinot noir' spaced at $1.4 \times 3.6 \mathrm{~m}$ in panels of five vines, and 'Riesling' spaced at $2.0 \times 2.9 \mathrm{~m}$ in panels of five vines. All the vines were cordon trained, spur pruned (about 20 nodes $/ \mathrm{m}$ ) on vertical trained canopies that were hedged around lag phase of berry development. The experimental design was a randomized complete block with four replicate panels for 'Chancellor' and five replicate panels for 'Pinot noir' and 'Riesling'. 'Chancellor' three vine replicates with half of vines of 1 and 3 as guards for disease evaluation, thus treatments were separated by two half vines. 'Pinot noir' and 'Riesling' five vine replications had vines one and five as guards for disease evaluation, thus treatments were separated by two buffer vines.

Microfloral assessment. Leaves and berries 
Table 1. Fungicide and clay application dates and rates for 'Chancellor', 'Pinot noir', and 'Riesling' grapes.

\begin{tabular}{|c|c|c|c|c|}
\hline \multirow[b]{3}{*}{$\begin{array}{l}\text { Application } \\
\text { date }\end{array}$} & \multirow{2}{*}{\multicolumn{2}{|c|}{$\frac{\text { Chancellor/Pinot noir/Riesling }^{2}}{\text { Applications in } 2000}$}} & \multirow{2}{*}{\multicolumn{2}{|c|}{$\begin{array}{c}\text { Chancellor } \\
\text { Applications in } 2001\end{array}$}} \\
\hline & & & & \\
\hline & $\begin{array}{l}\text { Fungicide }^{y} \\
(\mathrm{~g} / 100 \mathrm{~L})\end{array}$ & $\begin{array}{c}\text { Clay } \\
(\mathrm{kg} / 100 \mathrm{~L})\end{array}$ & $\begin{array}{l}\text { Fungicide } \\
(\mathrm{g} / 100 \mathrm{~L})\end{array}$ & $\begin{array}{c}\text { Clay } \\
(\mathrm{kg} / 100 \mathrm{~L})\end{array}$ \\
\hline 16 May & $\mathrm{M}(350)$ & Not applied & Not applied & Not applied \\
\hline 23 May & $\mathrm{M}(350)+\mathrm{K}(300)$ & Not applied & $N(20)$ & 2 \\
\hline 30 May & $\mathrm{D}(450)+\mathrm{K}(300)$ & Not applied & Not applied & Not applied \\
\hline 6 June & $\mathrm{M}(350)+\mathrm{N}(20)$ & 4 & $N(20)$ & 2 \\
\hline 27 June & $\mathrm{M}(350)+\mathrm{N}(20)$ & 4 & $\mathrm{~N}(20)$ & 2 \\
\hline 18 July & $\mathrm{M}(350)+\mathrm{K}(300)$ & 4 & $\mathrm{R}(150)+\mathrm{N}(20)$ & 2 \\
\hline 8 Aug. & $\mathrm{R}(150)+\mathrm{N}(20)$ & 4 & $\mathrm{R}(150)+\mathrm{N}(20)$ & 2 \\
\hline 29 Aug. & $\mathrm{R}(150)+\mathrm{K}(300)$ & 4 & Not applied & Not applied \\
\hline 6 Sept. & Not applied & Not applied & $\mathrm{R}(150)+\mathrm{N}(20)$ & 2 \\
\hline 12 Sept. & $\mathrm{M}(350)+\mathrm{K}(300)$ & 4 & Not applied & Not applied \\
\hline 21 Sept. & Not applied & Not applied & $\mathrm{R}(150)+\mathrm{N}(20)$ & 2 \\
\hline 28 Sept. & $\mathrm{M}(350)+\mathrm{K}(300)$ & 4 & Not applied & Not applied \\
\hline
\end{tabular}

${ }^{2}$ The first fungicide and clay applications were not made to 'Riesling' grapes until 6 June 2000.

${ }^{\mathrm{y}}$ Fungicides are abbreviated as follows: $\mathrm{M}=$ Maestro $75 \mathrm{DF}$ (captan); $\mathrm{K}=$ Kumulus 80 (sulphur); $\mathrm{D}=$ Dithane M 45 (mancozeb); $\mathrm{N}=$ Nova 40W (myclobutanil); ${ }^{6} \mathrm{R}=$ Rovral 50W (iprodione).

from the vineyard were sampled 2 to $3 \mathrm{~d}$ after each treatment application in 2000. See below for details on treatments. Ten leaves and five grape berries were collected from each center vine replication starting on 17 May for leaves, and 9 July 2000 for berries, respectively. Five leaves of similar dimensions from each replicate were pooled the following day into plastic bags for each treatment, with a total of 20 leaves or berries per treatment for 'Chancellor' and 25 leaves or berries per treatment for 'Pinot noir' and 'Riesling'. The fresh weight of the leaves and fruit were determined before they were placed in plastic bags. In total, $150 \mathrm{~mL}$ of $0.1 \mathrm{M}$ phosphate buffer $\mathrm{pH} 7.0$ was added to each bag to prevent $\mathrm{pH}$ shock and completely immerse leaves or berries in buffer for optimal removal of microflora. The sample bags were placed on a shaker rotating at $2.5 \mathrm{r} / \mathrm{s}$ for $20 \mathrm{~min}$ and then sonicated (Branson Ultrasonic Cleaners, Shelton, Conn.) for 10 min (Chand-Goyal and Spotts, 1996). The buffer wash from the bags was serially diluted in 10 -fold increments from 0 to $10^{-3}$ depending on earlier results of the undiluted wash. Aliquots of $0.1 \mathrm{~mL}$ were pipetted on two plastic petri plates $(100 \mathrm{~mm}$ diameter) containing $15 \mathrm{~mL}$ of medium. Four different types of media were used for detection of filamentous fungi, bacteria, and yeast: 1) lactic acid potato dextrose agar (LPDA) [1.5 $\mathrm{mL} 85 \%$ lactic acid in $1 \mathrm{~L}$ of potato dextrose agar (Difco Laboratories Inc. Detroit, Mich.)] was used for filamentous fungi (Andrews and Kenerley, 1978); 2) nutrient agar (NA) (Difco Laboratories Inc. Detroit, Mich.) was used for bacteria; 3) Pseudomonas agar (PS) F (Difco Laboratories Inc., Detroit, Mich.) was used for pseudomonads; and 4) yeast malt dextrose agar (YMD) [3.0 g Bacto yeast extract, $3.0 \mathrm{~g}$ Difco malt extract, $5.0 \mathrm{~g}$ Bacto peptone, 10.0 $\mathrm{g}$ Bacto dextrose, and $18.0 \mathrm{~g}$ Bacto agar (Difco Laboratories Inc. Detroit, Mich.)] was used for yeast (Chand-Goyal and Spotts, 1996). LPDA plates were incubated for 7 to $10 \mathrm{~d}$ at $20^{\circ} \mathrm{C}$ and the other plates were incubated for 48 to $72 \mathrm{~h}$ at $28^{\circ} \mathrm{C}$ before enumeration. The number of colony-forming-units (CFUs) of bacteria, fungi, and yeast per plate were counted based on colony characteristics such as pigmentation, size, opacity, form, elevation, margin, smooth- ness, texture, and spreading nature. Fungi were further characterized to the genus level by microscopically examining colony spores and confirming identification with diagnostic keys found in Barnett and Hunter (1998).

Vineyard spray trials. The treatments consisted of an unsprayed control, a nonswelling chlorite mica clay (Minerall Clay, Ironwood Clay Co., Richmond, B.C., Canada), and fungicide (various fungicides were used depending on grape spray program). Physical characteristics of the clay have been reported by Ehret et al. (1998). Fungicides were used at label rates and were applied 10 times in a spray program to control powdery mildew, bunch rot and phomopsis cane and leaf spot. Nova $40 \mathrm{~W}$ and Kumulus $\mathrm{S}$ were applied throughout the season for powdery mildew, Rovral 50W and Maestro 75 DF was applied four times during the season for bunch rot, and Maestro $75 \mathrm{DF}$ and Dithane were applied three times before bloom to control phomopsis cane and leaf spot. Nova was alternated with Kumulus, Rovral was alternated with Maestro because of concerns with fungicide resistance. The treatments were applied until runoff with a single nozzle gun sprayer operated at about $500 \mathrm{kPa}$ at a rate of $1000 \mathrm{~L} \cdot \mathrm{ha}^{-1}$. Details on rates, application dates, and fungicide used on a specific application date are found in Table 1. Incidence of powdery mildew on leaves were visually evaluated on all three grape cultivars on 1 Aug., 15 Sept., and 10 Oct. by examining 10 leaves on each of five shoots on the middle vine(s), and on five berry clusters from the middle vine(s) on 1 Aug. and 15 Sept. 2000. The percent leaf and cluster area covered with white mycelial growth symptomatic for powdery mildew was visually estimated to the nearest $10 \%$ of area. Fifty berry clusters were examined for white mycelial growth at harvest on 6 Oct. 2000 . 'Chancellor' was the only cultivar tested in 2001 with application details in Table 1 . The incidence of leaf and berry powdery mildew were evaluated as above on 5 Aug., 1 Sept., and 15 Oct. 2001. Fifty 'Chancellor' berry clusters were also examined at harvest on 11 Oct. 2001. Temperature and precipitation were monitored daily at the research centre weather station with a datalogger (Campbell Scientific
Canada Corp., Edmonton, Alta.) located about $1 \mathrm{~km}$ from the vineyard.

Data analysis. Microbial counts found on the various media types was determined for each fruit or leaf sample of 'Chancellor', 'Pinot noir', and 'Riesling' grapes on each sampling date. These numbers were combined to obtain the total sum of fungi, bacteria, pseudomonads, and yeast found on the different hosts over the 2000 growing season for each treatment. A two way analysis of variance was conducted using the three grape cultivars as blocks against six application dates followed by Bonferroni post tests (GraphPad Software Inc., San Diego, Calif.). Mean fungal, bacterial, pseudomonad, and yeast microfora ( $\log \mathrm{CFU} / \mathrm{g}$ tissue weight) were plotted at each application date and for each treatment standard error of the mean was shown with error bars (GraphPad Software Inc., San Diego, Calif.).

Powdery mildew incidence counts were obtained on all three cultivars in 2000 and only on 'Chancellor' in 2001. These values were arcsin-transformed because the values were originally recorded as percentages. The transformed data was subjected to analysis of variance with the General Linear Models Procedure (SAS Institute, Cary, N.C.) and the Duncan's multiple range test was used for separation of means $(P=0.05)$.

\section{Results}

Microflora found on grape leaves and berries. The number of microorganisms counted on untreated leaves and fruit totalled 174,749 CFU per g of tissue sampled in 2000 (Table 2). Of the three major categories of fungi, bacteria, and yeast, $76 \%$ of the colonies were bacteria, followed by $14 \%$ yeast and $9 \%$ fungi. The majority of bacteria (64\%) were composed of two colony types, transparent and white. The yeast were more widely distributed among colony types although over half $(8 \%)$ were pink colonies. The fungi which formed much larger colonies were spread over 15 genera although 10 genera composed $<0.1 \%$ of the total. The most common fungal genera were Aureobasidium spp. amounting to over half the fungal compliment of CFU/mL followed by Penicillium spp. with $2 \%$ of the total. $A s-$ pergillus spp. amounted to only $0.02 \%$ with the highest number on 'Riesling'. Botrytis spp. was found on all three cultivars with the highest number on 'Chancellor'. A relatively high percentage $(1.4 \%)$ of the fungi occurred only as mycelium and could not be identified. Propagules of grape microflora on leaves and fruit were combined by type of microflora (Fig. 1). The difference between microflora on berries and leaves was not significant but there was a significant difference between microfora $(P=0.03)$.

Effect of treatment on grape microflora. Highly significant treatment differences were found for fungal microflora on both berries and fruit (Table 3). Graphical treatment of the data showed that the differences on berries (Fig. 2) and leaves (Fig. 3) were between the fungicide and the other two treatments. Fungal microflora was reduced to very low levels on 
Table 2. Number of colony-forming-units (CFUs) per g of grape leaf and fruit tissue of microflora sampled in 2000 at Summerland, British Columbia, Canada.

\begin{tabular}{|c|c|c|c|c|c|}
\hline \multirow{2}{*}{$\begin{array}{l}\text { Microfora genera } \\
\text { or distinguishing } \\
\text { character }\end{array}$} & \multicolumn{3}{|c|}{ CFUs (no.)/g of tissue wt } & \multirow{2}{*}{$\begin{array}{l}\text { Total } \\
\text { count }\end{array}$} & \multirow{2}{*}{$\begin{array}{l}\text { Percent } \\
\text { of total }\end{array}$} \\
\hline & Chancellor & Pinot noir & $\overline{\text { Riesling }}$ & & \\
\hline \multicolumn{6}{|l|}{ Fungal genera } \\
\hline Alternaria & 327 & 239 & 325 & 891 & 0.51 \\
\hline Aspergillus & 9 & 10 & 16 & 35 & 0.02 \\
\hline Aureobasidium & 1,626 & 1,847 & 4,666 & 8,139 & 4.65 \\
\hline Botrytis & 33 & 16 & 20 & 69 & 0.04 \\
\hline Cladosporium & 335 & 178 & 300 & 813 & 0.47 \\
\hline Epicoccum & 5 & 5 & 8 & 18 & 0.01 \\
\hline Geotrichum & 28 & 1 & 16 & 45 & 0.03 \\
\hline Monilinia & 10 & 2 & 1 & 13 & 0.01 \\
\hline Mucor & 2 & 0 & 3 & 5 & 0.001 \\
\hline Penicillium & 354 & 3,224 & 193 & 3,771 & 2.16 \\
\hline Periconia & 1 & 6 & 0 & 7 & 0.001 \\
\hline Pseudobotrytis & 0 & 0 & 8 & 8 & 0.001 \\
\hline Sporobolomyces & 0 & 0 & 2 & 2 & 0.001 \\
\hline Trichoderma & 0 & 0 & 52 & 52 & 0.03 \\
\hline Miscellaneous & 1,046 & 269 & 1,122 & 2,437 & 1.39 \\
\hline Total fungi & 3,776 & 5,797 & 6,739 & 16,312 & 9.33 \\
\hline \multicolumn{6}{|l|}{ Bacterial genera } \\
\hline Bacillus & 386 & 2,134 & 73 & 2,593 & 1.48 \\
\hline Cream & 1,342 & 4,014 & 3,843 & 9,199 & 5.25 \\
\hline Egg yolk & 349 & 1,789 & 190 & 2,328 & 1.33 \\
\hline Fluorescent & 396 & 206 & 551 & 1,153 & 0.66 \\
\hline Orange & 79 & 75 & 104 & 258 & 0.15 \\
\hline Pink & 8 & 109 & 86 & 203 & 0.11 \\
\hline Transparent & 20,159 & 30,554 & 9,117 & 59,830 & 34.24 \\
\hline White & 8,200 & 24,011 & 19,561 & 51,772 & 29.62 \\
\hline Yellow & 698 & 2,053 & 1,191 & 3,942 & 2.26 \\
\hline Miscellaneous & 249 & 561 & 122 & 932 & 0.53 \\
\hline Total bacteria & 31,866 & 65,506 & 34,838 & 132,210 & 75.66 \\
\hline \multicolumn{6}{|l|}{ Yeast genera } \\
\hline Cream & 1,316 & 3,804 & 1,156 & 6,276 & 3.58 \\
\hline Orange & 408 & 92 & 159 & 659 & 0.38 \\
\hline Peach & 27 & 100 & 51 & 178 & 0.10 \\
\hline Pink & 1,536 & 11,234 & 1,370 & 14,140 & 8.08 \\
\hline White & 1,553 & 512 & 1,909 & 3,974 & 2.28 \\
\hline Miscellaneous & 29 & 3 & 50 & 82 & 0.04 \\
\hline Total yeast & 4,869 & 15,745 & 4,695 & 25,309 & 14.48 \\
\hline Total microflora & 40,511 & 87,966 & 46,272 & 174,749 & 100.00 \\
\hline
\end{tabular}

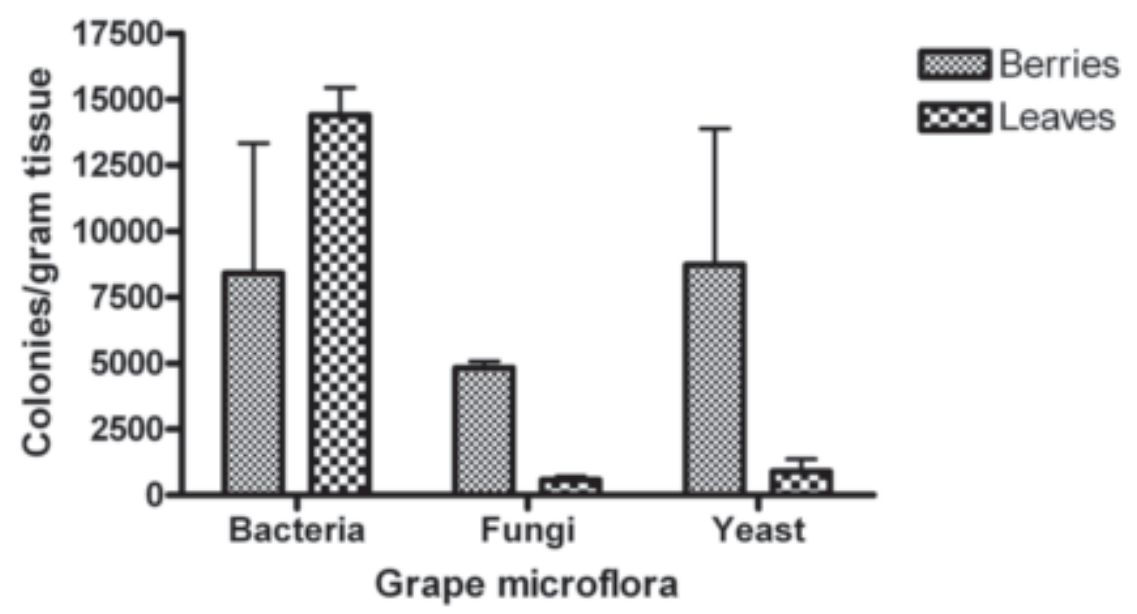

Fig. 1. Total number of colonies per gram of tissue of bacteria, fungi and yeast microflora from grape berries and leaves over the 2000 growing season at PARC, Summerland, BC, Canada. Error bars represent SE of three replications.

Table 3. Two-way analysis of variance of treatment (fungicide, clay, untreated) and sampling dates (June to September 2000) for microflora found on grape berries and leaves.

\begin{tabular}{lcccc}
\hline Source for berries & Fungal & Bacteria & Pseudomonads & Yeast \\
\hline Date (D) & $* * *$ & $* * *$ & $* * *$ & $* * *$ \\
Treatment (T) & $* * *$ & $*$ & NS & $* * *$ \\
D $\times$ T & NS & NS & NS & NS \\
Source for leaves & & & $* * *$ & $* * *$ \\
Date (D) & NS & $* * *$ & NS & $*$ \\
Treatment (T) & NS & NS & NS & NS \\
D $\times$ T & NS,$* * * * *$ Nonsignificant or significant at $P \leq 0.05,0.01,0.001$, respectively. & &
\end{tabular}

both berries and leaves throughout the season by the fungicide treatment. Bacterial microflora was not affected as much as fungal microflora and treatment differences were only detected on berries (Table 3). Again the treatment that affected bacterial microflora on berries was the fungicide treatment (Fig. 2). There were no treatment differences for pseudomonads analyzed as an independent class of bacteria on either berries or leaves (Table 3) although relatively high numbers of these bacteria were recorded throughout the growing season (Figs. 2 and 3). Highly significant treatment differences were found for yeast microflora on grape berries (Table 3 ). The fungicide treatment reduced yeast microflora compared to clay treated or untreated berries (Fig. 2). Very few yeast propagules were found on grape leaves but towards the end of the growing season the fungicide treatment reduced their numbers as it did on berries (Fig. 3).

Effect of sampling date on grape microflora. The day on which grape berries were sampled throughout the growing season significantly influenced numbers of fungal, bacterial, pseudomonad, and yeast microflora that were sampled (Table 3). There was only one instance where sampling date did not affect microflora and this instance was on fungal microflora on leaves. Generally number of colonies of fungal and yeast microflora on berries increased over the season while bacterial and pseudomonad microflora increased early but remained relatively constant over the season (Fig. 2). On leaves, fungal, bacterial, and pseudomonad microflora were relatively constant over the season with the exception of yeast microflora that increased at the end of the season (Fig. 3).

Statistical analysis showed that there were no significant differences between clay treated or untreated berries or leaves on any sampling date for fungal microflora (Table 4). On the other hand there were significant differences for fungicide treated berries and leaves versus clay or untreated berries and leaves on several sampling dates. Bonferroni post test analysis of fungicide versus clay, fungicide versus untreated, or clay versus untreated berries were not significantly different for pseudomonads or yeast microflora. The only exception was for bacterial microflora on 29 June for fungicide versus clay where a significant difference was recorded. There were no significant differences for bacterial or pseudomonad microflora on leaves. The only exception was for yeast microflora on 28 Sept. for fungicide versus clay where a significant difference was recorded.

Effect of temperature and precipitation on microfora. The effect of temperature (Fig. 4) on grape fungal and yeast microfora was an inverse relationship because cooler temperatures beginning around the $17 \mathrm{Aug} .2000$ (day 230) generally corresponded to higher counts on berries (Fig. 2). On leaves the trend was only noticed on yeast microfora (Fig. 3). Rain over $5 \mathrm{~mm} \cdot \mathrm{d}^{-1}$ occurred 5 times during the season (Fig. 4) with the highest rainfall of $10.6 \mathrm{~mm}$ recorded on 9 June 2000 (day 161). Significant rainfall was also recorded on the 21 and 22 July (days 203 and 204), 2 Sept. (day 246), and 28 Sept. 2000 (day 272). The effect 

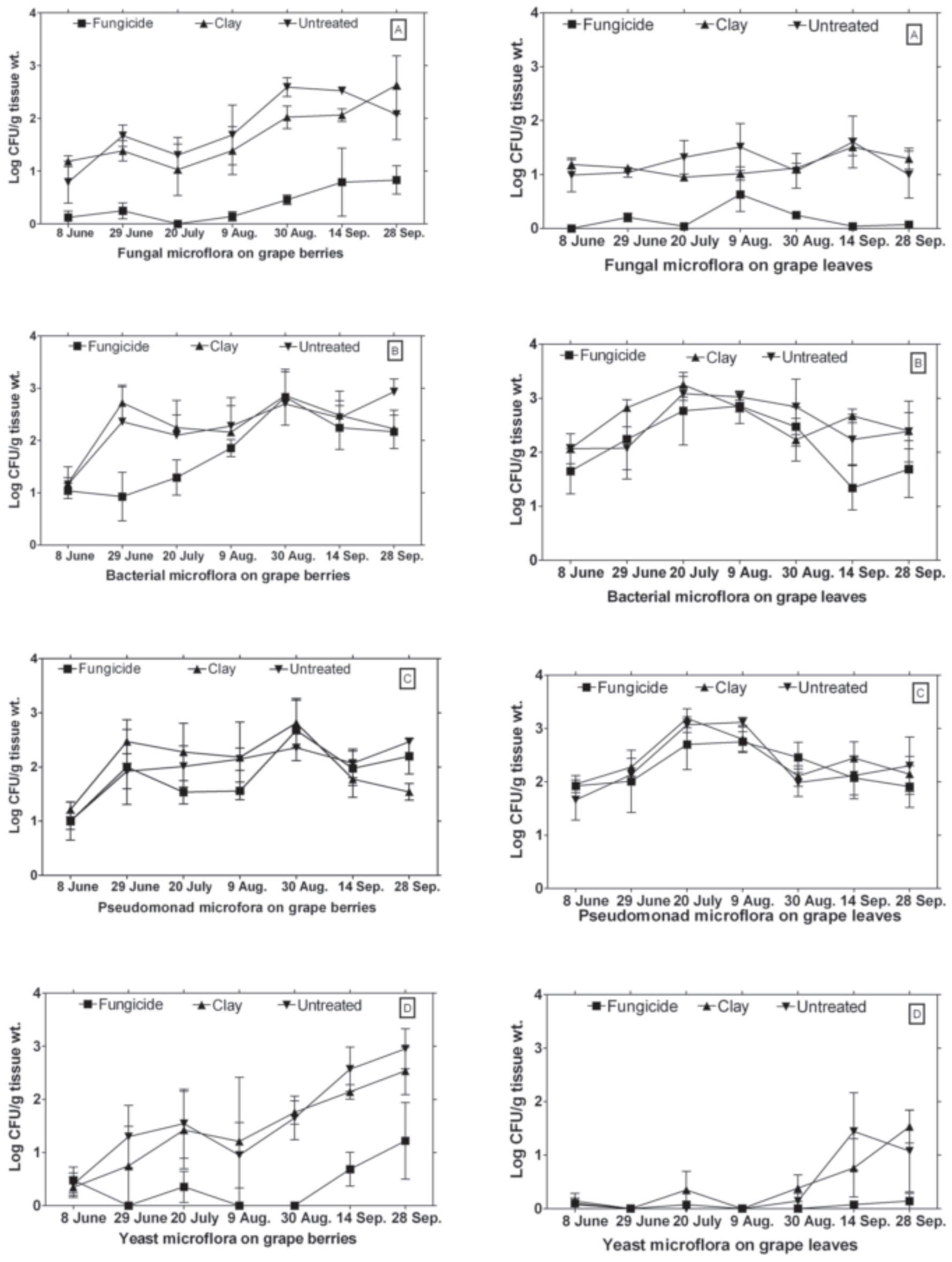

Fig. 2. Mean number of colonies of fungal (A), bacterial (B), Pseudomonad (C), or yeast (D) microflora per sampling date from grape berries treated with fungicides, clay, or left untreated. Error bars represent SE of three replications.

Fig. 3. Mean number of colonies of fungal (A), bacterial (B), Pseudomonad (C), or yeast (D) microflora per sampling date from grape leaves treated with fungicides, clay, or left untreated. Error bars represent SE of three replications. 
Table 4. Bonferroni posttest analysis of fungal microflora on fruit and leaves of grapes by contrasting each treatment by sampling date.

\begin{tabular}{|c|c|c|c|c|c|c|}
\hline \multirow{2}{*}{$\begin{array}{l}\text { Sampling } \\
\text { date }\end{array}$} & \multicolumn{2}{|c|}{ Fungicide vs. clay } & \multicolumn{2}{|c|}{ Fungicide vs. untreated } & \multicolumn{2}{|c|}{ Clay vs. untreated } \\
\hline & Berries & Leaves & Berries & Leaves & Berries & Leaves \\
\hline 8 June & NS & ** & NS & * & NS & NS \\
\hline 29 June & NS & * & * & NS & NS & NS \\
\hline 20 July & NS & * & NS & ** & NS & NS \\
\hline 9 Aug. & NS & NS & * & NS & NS & NS \\
\hline 30 Aug. & * & NS & *** & NS & NS & NS \\
\hline 14 Sept. & NS & $* * *$ & ** & *** & NS & NS \\
\hline 28 Sept. & ** & ** & NS & NS & NS & NS \\
\hline
\end{tabular}

NS,***,***Nonsignificant or significant at $P \leq 0.05,0.01,0.001$, respectively.

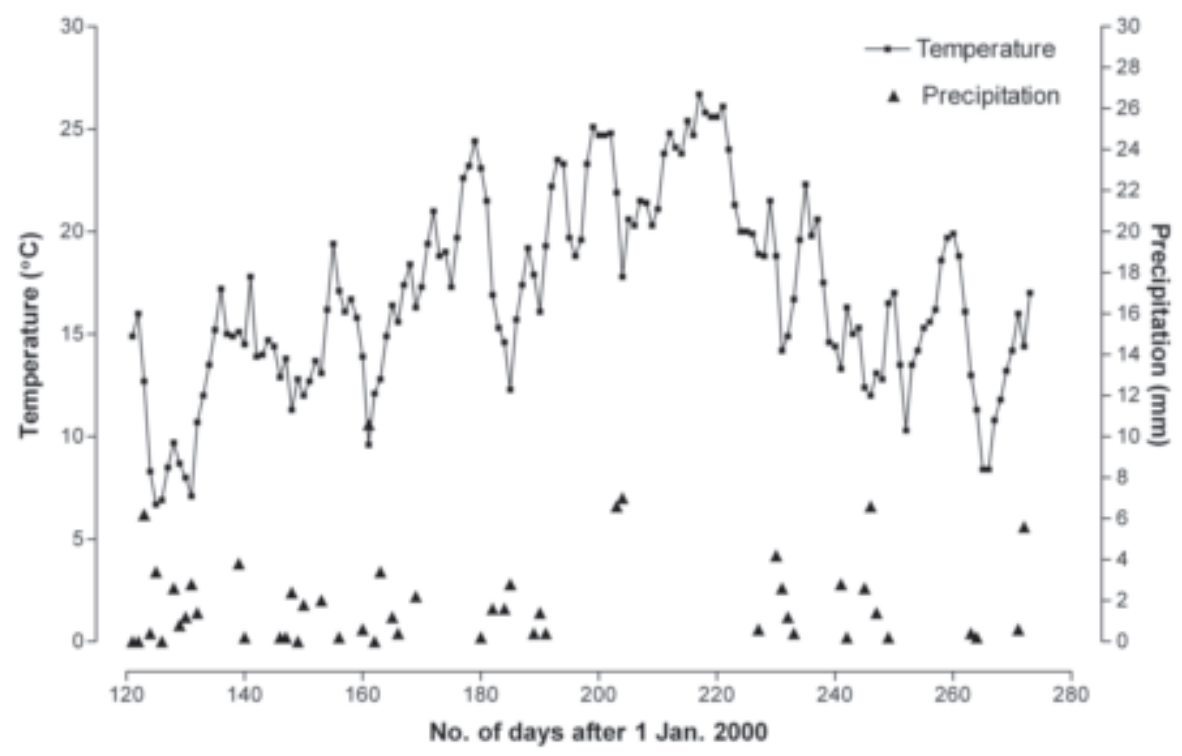

Fig. 4. Mean daily temperature and precipitation at PARC, Summerland, BC, Canada from 30 Apr. 2000 (day 120) to 30 Sept. 2000 (day 274). Measurements were taken at a weather station located about 0.5 $\mathrm{km}$ from the grape research plot.
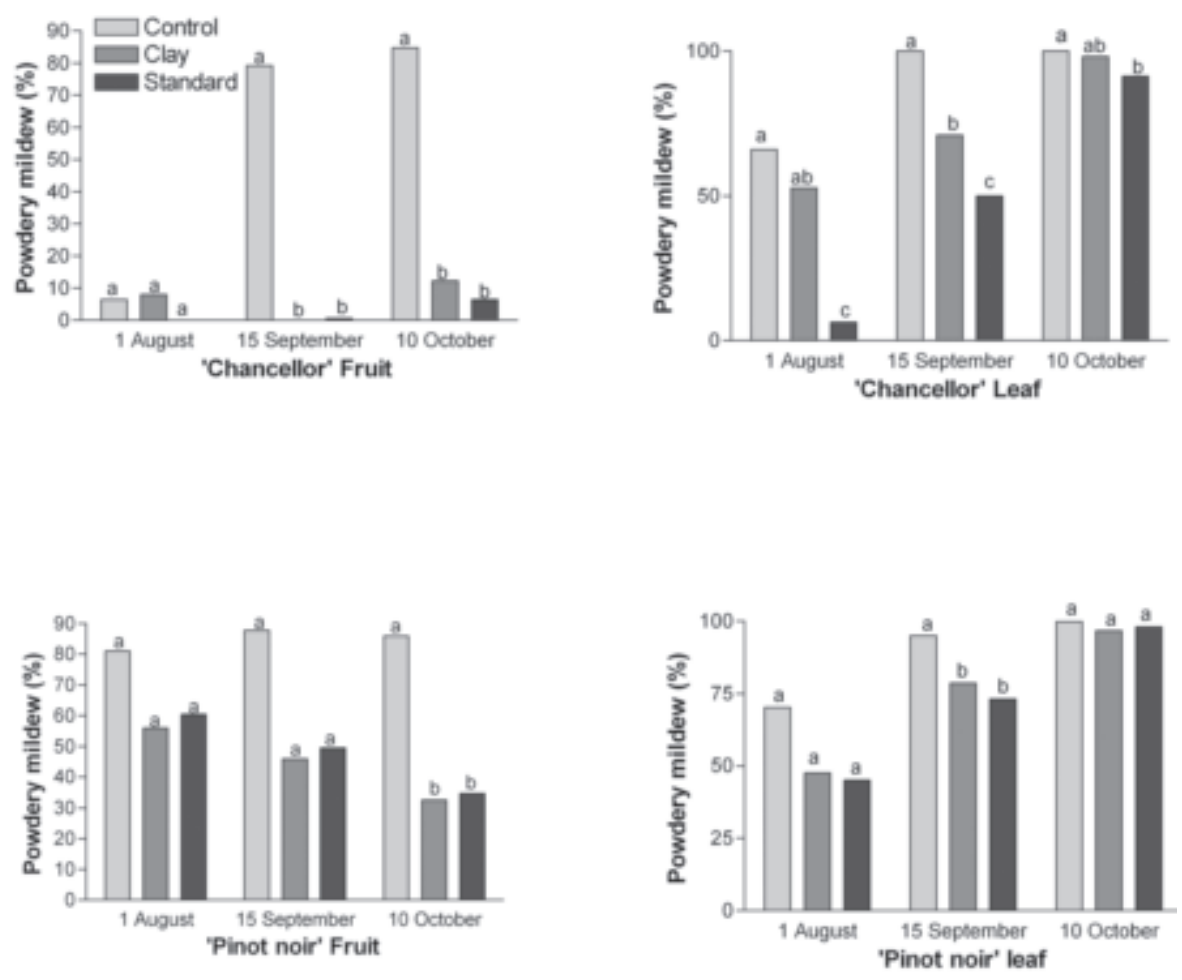

Fig. 5. Effect of treatment regime (untreated control, clay treatment, and standard fungicide treatment) on percent incidence of powdery mildew on 'Chancellor' and 'Pinot noir' fruit and leaves on 1 Aug., 15 Sept., and 10 Oct. 2000. Vertical bars with the same letter within a date are not significantly different according to Duncan's multiple range test $(P=0.05)$. of this rainfall or its absence on microflora was not clear.

Effect of clayorfungicide on grape powdery mildew. In 2000 neither the standard fungicide or clay treatments had any significant effect on powdery mildew of 'Riesling' grapes (data not shown). In 'Chancellor' treatments with clay or fungicides were very effective in controlling powdery mildew on berries once the disease developed to significant levels on 15 Sept. and 10 Oct. 2000 (Fig. 5). The treatments were less effective on 'Pinot noir' grape berries only controlling the disease late in the season on 10 Oct., 2000. Control of leaf powdery mildew with clay was not significantly different than the control after two of three incidence ratings but was effective after the most important reading on 15 Sept. 2000. The standard fungicide treatment was effective on all three reading dates reducing powdery mildew incidence on 'Chancellor' leaves to lower levels than clay. Levels of powdery mildew on 'Pinot noir' leaves were reduced by both clay and fungicides on 15 Sept. although both treatments were ineffective on 1 Aug. and 10 Oct. 2000.

In 2001 the 'Chancellor' trial was repeated demonstrating that clay was an effective treatment for control of powdery mildew on grape berries (Fig. 6). Once again it was not as effective as the fungicide treatments were over the growing season on 'Chancellor' grape foliage.

\section{Discussion}

The microflora found on grape foliage and berries of vinifera ('Pinot noir' and Riesling') and hybrid ('Chancellor') grape cultivars used in this study was a complex mixture consisting of several types of bacteria, yeast, and fungi. At least nine specific bacterial colony types were prevalent over the growing season. Bell et al. (1995) studied endophytic bacteria in grapevine and of 100 randomly selected strains from a variety of grape cultivars found that most were Gram-negative species with Pseudomonas (28 strains) and Enterobacter (17 strains) predominating. This diversity of bacterial species found endophytically in grape vine appears to reflect the bacterial microflora found on grape leaves and fruit in the present study. It appears that this complex of bacteria are relatively resistant to fungicides used on grapes because their numbers remained stable on berries and leaves treated with fungicides.

Davenport (1976), studying yeast populations on developing grapes, showed that the population is made up of resident species that are occasionally augmented with transitional species. The principal yeast microflora associated with grape vineyards is comprised of non-fermentative species different from those found during grape juice fermentation (Villa and Longo, 1996). Buck and Andrews (1999) recognized that characteristics such as wettability and exogenous nutrients can dramatically shape yeast populations. In the present study three yeast species consisting of cream, pink, and white colonies predominated with the colonies evenly distributed on 'Chancellor' and 'Riesling', however with 'Pinot noir' the 


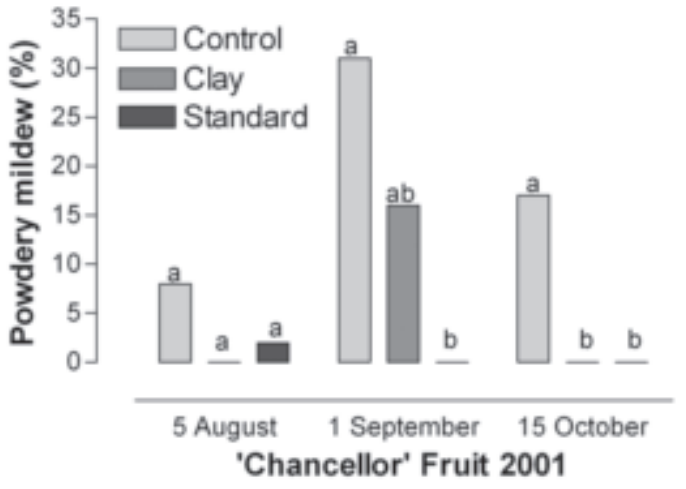

Fig. 6. Effect of treatment regime (untreated control, clay treatment, and standard fungicide treatment) on percent incidence of powdery mildew on 'Chancellor' fruit and leaves on 5 Aug., 1 Sept., and 15 Oct., 2001. Vertical bars with the same letter within a date are not significantly different according to Duncan's multiple range test $(P=0.05)$.

pink colonies accounted for $>70 \%$ of the yeast population out numbering all otheryeast species. Yeast colonies were found on berries right up to harvest where grape fermentation could be impacted. Most note worthy was that fungicides applied to grape berries dramatically reduced the yeast population.

Most of the fungal species found on grapes in this study were likely epiphytes although some plant pathogens and potentially mycotoxin-producing fungi were present. The bunch rot causal agent, Botrytis spp. was present in relatively high numbers on untreated 'Chancellor' grapes (Table 2). This was not surprising because bunch rot is commonly found in the vineyard used for the present investigation. Postharvest pathogens such as Penicillium, and Aspergillus spp. were also found on untreated grapes, with numbers of Penicillium spp. reaching very high levels that could lead to decay if these grapes were kept very long before crushing. Penicillium spp. produce mycotoxins on cereal grains and other foods (Ominski et al., 1994) and the potential for production of mycotoxins on grape berries would be important for wine quality. Aspergillus spp., known to produce aflatoxin and Ochratoxin A, is even more of a concern because of the extreme toxicity of these mycotoxins (Battilani, 2003). Fortunately, Aspergillus spp. were found in very low numbers. Interestingly, Monilinia spp. was found in the grapes here investigated likely coming from nearby infected stone fruit. This fungus, which causes brown rot, was recently reported on grapes in Canada (Sholberg et al., 2003).

The use of chemical fungicides to control grape diseases applied 12 times over the growing season had a major impact on the fungal microflora. The fungicide treatment reduced fungal epiphytes on berries to low levels and eliminated almost all the fungal epiphytes from leaves. Andrews and Kenerley (1978) found a similar effect on apple microflora with fungal populations on treated leaves less diverse than on control leaves. They speculated that metiram (Polyram), a wide spectrum fungicide was most likely responsible for reducing the epiphytic microflora on apples. In this study captan (Maestro), a wide spectrum fungicide, was used six times both early and late in the season and could have been the fungicide most responsible for reducing epiphytic populations. Andrews and Kenerley (1978) concluded that the disruptive effect of metiram could slow down the breakdown of leaves and promote overwintering of the apple scab fungus. Similarly, fungicides used in grape pest management could slow breakdown of grape leaves and bark and thus promote overwintering of grape pathogens such as Botrytis cinerea and Erysiphe necator.

The use of clay was generally less disruptive than fungicides to grape berry and leaf microflora. Manning (1971) found similar results with limestone dust from quarries and processing plants. The dust increased numbers, but not kinds, of bacteria and fungi when compared to dust-free grape leaves. This study showed pseudomonads were only slightly affected by fungicides and relatively large populations lived on berries and leaves throughout the season. Stockwell et al. (2002) found that on pear stigmas the ubiquitous fluorescent pseudomonads provided suppression of Erwinia amylovora. In this study the presence of fluorescent pseudomonads did not translate into better control of powdery mildew by clay. It could be that fluorescent pseudomonads are only antagonistic to bacterial pathogens. This is supported by the fact that fluorescent pseudomonads are not used for biological control of powdery mildew (Bélanger and Labbé, 2002).

When a pathogen lands on a susceptible leaf or fruit it is directly affected by the resident population of epiphytes. By supporting nonpathogenic microflora on grape berries clay could help protect them from infection. Only $1 \%$ to $5 \%$ of bunches from grape batches need to be infected with $E$. necator for detectable changes to occur in wine quality (Stummer et al., 2005). In this study epiphytic microflora could have had an effect on 'Chancellor' berries treated with clay (Fig. 5). These berries had almost zero powdery mildew although the control berries were heavily infected. The clay either supported the microflora that was antagonistic to powdery mildew or the clay itself prevented the growth of E. necator by acting as a physical barrier and/or it induced resistance in the host (Bélanger and Labbé,

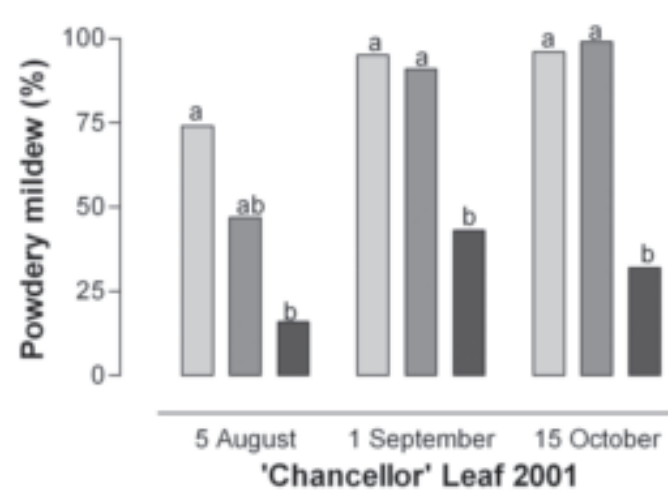

2002). The clay used in this study differs from kaolin clay that was used for suppression of arthropod pests and plant diseases by Glenn et al. (1999). Kaolin clay is thought to prevent plant diseases by acting as a particle film barrier preventing disease inoculum from directly contacting plant tissue and by preventing liquid water from directly contacting the leaf surface. Less disruptive disease control strategies may evolve from a better understanding of the ecology of epiphytic bacteria (Hirano and Upper, 1983), fungi, and yeast and their affect on wine quality.

It would be interesting to compare the microflora from British Columbia wine grapes with other regions to see if there is any correlation between microflora and wine quality. Microflora could be an important factor in the concept of terroir used to explain wine quality from one region to another. Terroir is defined by grape growers as the reason why a group of vineyards from the same region, with the same grapes and soil type produce a unique wine.

In conclusion, wine grape berries and leaves have a diverse and abundant microflora consisting of many species of bacteria, pseudomonads, fungi, and yeasts. Numbers of propagules on both berries and leaves fluctuates up and down to factors such as sampling date, temperature, precipitation, and pest management practices used in the vineyard. The overall number of microorganisms especially fungi and yeasts are reduced by fungicide treatments used to control plant diseases. Clay as a treatment to tive on microflora and could provide benefits for grape pest management and wine quality by conserving epiphytic microflora.

\section{Literature Cited}

Andrews, J.H. 1992. Biological control in the phyllosphere. Annu. Rev. Phytopathol. 30:603-635.

Andrews, J.H. and C.M. Kenerley. 1978. The effects of a pesticide program on non-target epiphytic microbial populations of apple leaves. Can. J.

Andrews, J.H. and J.W. Buck. 2002. Adhesion of yeasts to leaf surfaces, p. 53-68. In: S.E. Lindow, E.I. Hecht-Poinar, and V.J. Elliot (eds.). Phyllosphere microbiology. APS Press, St. Paul, Minn.

Battilani, P. 2003. Epidemiology of toxin-producing fungi and ochratoxin A occurrence in grape. Euro. J. Plant Pathol. 109:715-722.

Barnett, H.L. and B.B. Hunter. 1998. Illustrated genera of imperfect fungi. 4th ed. APS Press, St. Paul, Minn.

Bélanger, R.R. and C. Labbé. 2002. Control of powdery mildew without chemicals: Prophylactic and biological alternatives for horticultural crops, p. 256-267. In: R.R. Bélanger, W.R. Bushnell, A.J. Dik, and T.L.W. Carver (eds.). The powdery mildews: A comprehensive treatise. APS Press, St. Paul, Minn.

Bell, C.R., G.A. Dickie, W.L.G. Harvey, and J.W.Y.F. Chan. 1995. Endophytic bacteria in grapevine. control powdery mildew is much less disrupMicrobiol. 24:1058-1072. 
Can. J. Microbiol. 41:46-53.

Buck, J.W. and J.H. Andrews. 1999. Attachment of the yeast Rhodosporidium toruloides is mediated by adhesives localized at sites of bud cell development. Appl. Environ. Microbiol. 65:465-471.

Calonnec, A., P. Cartolaro, C. Poupot, D. Dubourdier, and P. Darriet. 2004. Effects of Uncinula necator on the yield and quality of grapes (Vitis vinifera) and wine. Plant Pathol. 53:434-445.

Chand-Goyal, T. and R.A. Spotts. 1996. Enumeration of bacterial and yeast colonists of apple fruits and identification of epiphytic yeasts on pear fruits in the Pacific Northwest United States. Microbiol. Res. 151:427-432.

Davenport, R.R. 1976. Distribution of yeasts and yeast-like organisms from aerial surfaces of developing apples and grapes, p. 325-359. In: C.H. Dickinson and T.F. Preecee (eds.). Microbiology of aerial plant surfaces. Academic Press, London.

Ehret, D.L., B.J. Zebarth, J. Portree, and T. Garland. 1998.Clay addition to soilless media promotes growth and yield of greenhouse crops. HortScience 33:67-70.

Ehret, D.L., C. Koch, J. Menzies, P. Sholberg, and T. Garland. 2001. Foliar sprays of clay reduce the severity of powdery mildew on long English cucumber and wine grapes. HortScience 36:934-936.

Fokkema, N.J., J.G. den Houter, Y.J.C. Kosterman, and A.L. Nelis. 1979. Manipulation of yeasts on field grown wheat leaves and their antagonistic effect on Cochliobolus sativus and Septoria nodorum. Trans. Br. Mycol. Soc. 72:19-29.

Gadoury, D.M., R.C. Seem, R.C. Pearson, W.F. Wilcox, and R.M. Dunst. 2001. Effects of powdery mildew on vine growth, yield, and quality of Concord grapes. Plant Dis. 85:137-140.

Glenn, D.M., G.J. Puterka, T. Vanderzwet, R.E. Byers, and C. Feldhake. 1999. Hydrophobic particle films: A new paradigm for suppression of arthropod pests and plant diseases. J. Econ.
Entomol. 92:759-771.

Hirano, S.S. and C.D. Upper. 1983. Ecology and epidemiology of foliar bacterial plant pathogens. Annu. Rev. Phytopathol. 21:243-269.

Jutsum, A.R., S.P. Heaney, B.M. Perrin, and P.J. Wege. 1998. Pesticide resistance: Assessment of risk and the development and implementation of effective management strategies. Pesticide Sci. 54:435-446.

Kinkel, L.L., M. Wilson, and S.E. Lindow. 2000. Plant species and plant incubation conditions influence variability in epiphytic bacterial population size. Microbiol. Ecol. 39:1-11.

Leben, C. 1965. Epiphytic microorganisms in relation to plant disease. Annu. Rev. Phytopathol. 3:209-230.

Lindow, S. E. 1996. Role of immigration and other processes in determining epiphytic bacterial populations, p. 155-168. In: C.E. Morris, P.C. Nicot, and C. Nguyen-The (eds.). Aerial plant surface microbiology. Plenum Press, New York.

Longo, E., J. Cansado, D. Agrelo, and T.G. Villa. 1991. Effect of climatic conditions on yeast diversity in grape musts from northwest Spain. Amer. J. Enol. Viticult. 42:141-144.

Manning, W.J. 1971. Effects of limestone dust on leaf condition, foliar disease incidence, and leaf surface microflora of native plants. Environ. Pollut. 2:69-76.

Northover, J. and K.E. Schneider. 1996. Physical modes of action of petroleum and plant oils on powdery and downy mildews of grapevines. Plant Dis. 80:544-550.

Ominski, K.H., R.R. Marquardt, R.N. Sinha, and D. Abramson. 1994. Ecological aspects of growth and mycotoxin production by storage fungi, $\mathrm{p}$. 287-312. In: J.D. Miller, and H.L. Trenholm (eds.). Mycotoxins in grain compounds other than Aflatoxin. Eagan Press, St. Paul, Minn.

Pearson, R.C. 1988. Powdery mildew, p. 9-11. In: R.C. Pearson and A.C. Goheen (eds.). Compendium of grape diseases. APS Press, St. Paul, Minn.
Reynolds, A.G., L.J. Veto, P.L. Sholberg, D.A. Wardle, and P. Haag. 1996. Use of potassium silicate for the control of powdery mildew [Uncinula necator (Schwein) Burill] in Vitis vinifera L. cultivar Bacchus. Amer. J. Enol. Viticult. 47:421-428.

Sholberg, P.L. 2004. Management of grape diseases in arid climates, p. 53-80. In: S.A.M.H. Naqvi (ed.). Diseases of fruits and vegetables, diagnosis and management. vol. 2. Kluwer Academic Publishers, Dordrecht.

Sholberg, P.L. and J. Boulé. 2001. Efficacy of Minerall clay for control of powdery mildew and leafhoppers on grapes, 1999. Biological Cult. Tests 16:N60.

Sholberg, P.L., P. Haag, S. Hambleton, and H. Boulay. 2003. First report of brown rot in wine grapes caused by Monilinia fructicola in Canada. Plant Dis. 87:1268.

Stockwell, V.O., K.B. Johnson, and J.E. Loper. 2002. Biological control of fire blight: understanding interactions among introduced and indigenous microbial communities, p. 225-240. In: S.E. Lindow, E.I. Hecht-Poinar, and V.J. Elliot. Phyllosphere microbiology. APS Press, St. Paul, Minn.

Stummer, B.E., I.L. Francis, T. Zanker, K.A. Lattey, and E. Scott. 2005. Effects of powdery mildew on the sensory properties and composition of Chardonnay juice and wine when grape sugar ripeness is standardised. Austral. J. Grape Wine Res. 11:66-76.

Upper, C.D. and S.S. Hirano. 2002. Revisiting the roles of immigration and growth in the development of populations of Pseudomonas syringae in the phyllosphere, p. 69-79. In: S.E. Lindow, E.I. Hecht-Poinar, and V.J. Elliot. Phyllosphere microbiology. APS Press, St. Paul, Minn.

Villa, T.G. and E. Longo. 1996. Microbiology of grape surfaces and its importance for wine quality, p. 207-212. In: C.E. Morris, P.C. Nicot, and C. Nguyen-The (eds.). Aerial plant surface microbiology, Plenum Press, New York. 